\title{
Features
}

\section{Approaches to Cell Biology Teaching: Learning Content in Context-Problem-Based Learning}

\author{
Deborah Allen* ${ }^{*}$ and Kimberly Tanner ${ }^{\dagger}$
}

\author{
*Department of Biological Sciences, University of Delaware, Newark, Delaware 19716, and ${ }^{\dagger}$ University of \\ California at San Francisco (UCSF), Science \& Health Partnership (SEP), San Francisco, California 94143-0905
}

Submitted April 9, 2003; Revised April 16, 2003; Accepted April 16, 2003

In answering the call of the American Association for the Advancement of Science (1990) that "science should be taught as science is practiced at is best," science faculty across the country have systematically begun to infuse their skills, perspectives, and experiences as scientists into the instructional approaches they select for their undergraduate classrooms. Problem-based learning (PBL), which diffused into undergraduate science instruction from the medical school setting over 10 years ago, is one of those approaches. Use of PBL in the undergraduate setting has steadily grown in popularity over the past decade (Samford University, PBL Initiative), at least in part because its inquiry-driven nature and underlying philosophies resonate with these comments from the recent Boyer Commission Report (1998) on undergraduate education at research universities:

\begin{abstract}
The research university must facilitate inquiry in such contexts as the library, the laboratory, the computer, and the studio, with the expectation that senior learners, that is, professors, will be students' companions and guides.... The research university's ability to create such an integrated education will produce a particular kind of individual, one equipped with a spirit of inquiry and a zest for problem solving; one possessed of the skill in communication that is the hallmark of clear thinking as well as mastery of language; one informed by a rich and diverse experience. It is that kind of individual that will provide the scientific, technological, academic, political, and creative leadership for the next century.
\end{abstract}

Problem-based learning, the modern origins of which can be traced to the medical schools at Case Western Reserve University (in the 1950s) and McMaster University in Canada (in the 1960s) was devised as a way to educate physicians to use their content knowledge in the context of real patients (Barrows and Tamblyn, 1980; Boud and Feletti, 1998). Early implementation of PBL also signaled a shift in how medical educators chose to deal with the rapidly and exponen-

DOI: $10.1187 /$ cbe.03-04-0019

‡Corresponding author. E-mail address: deallen@udel.edu. tially expanding professional knowledge base-PBL strategies shifted emphasis away from increasingly more difficult demands for information assimilation toward development of students' ability to learn effectively and independently. And finally, PBL was viewed as a way to align classroom practices with professional practices beyond the confines of medical school (Boud and Feletti, 1998). Many of these same concerns and issues are faced by nearly every science instructor nationwide (National Science Foundation, 1997).

\section{WHAT IS PROBLEM-BASED LEARNING?}

In the PBL process, learning is initiated by and structured around complex problems rooted in situations that the learner is likely to encounter in the world outside of school (Woods, 1985) (Figure 1). Working in collaborative groups, students define and analyze the problem, identify and find needed information (by posing and answering their own and peers' questions), share the results of their investigations, and formulate and evaluate possible solutions. The PBL process resembles in many respects the essential features of scholarly inquiry-its processes and objectives align in fundamental ways with those of the undergraduate research experience, making such learning opportunities accessible to a broader population of students.

How is PBL different from other types of classroom problem-solving activities? It is not necessarily different in any single way but has a particular combination of essential features. These include the nature of the problem and how it is used and the way in which PBL formalizes the problemresolving activities. PBL problems are ill structured-they intentionally fail to provide all the information necessary to develop a solution, introducing uncertainty about the path toward resolution as well as about the goals (Qin et al., 1995). The ill-structured and problematic nature of PBL problems is designed to create an imbalance or "cognitive dissonance" (Festinger, 1962) in the learner that (in addition to the problem's real-world context) motivates a search for explanations. In PBL, engagement in the problem comes before any 


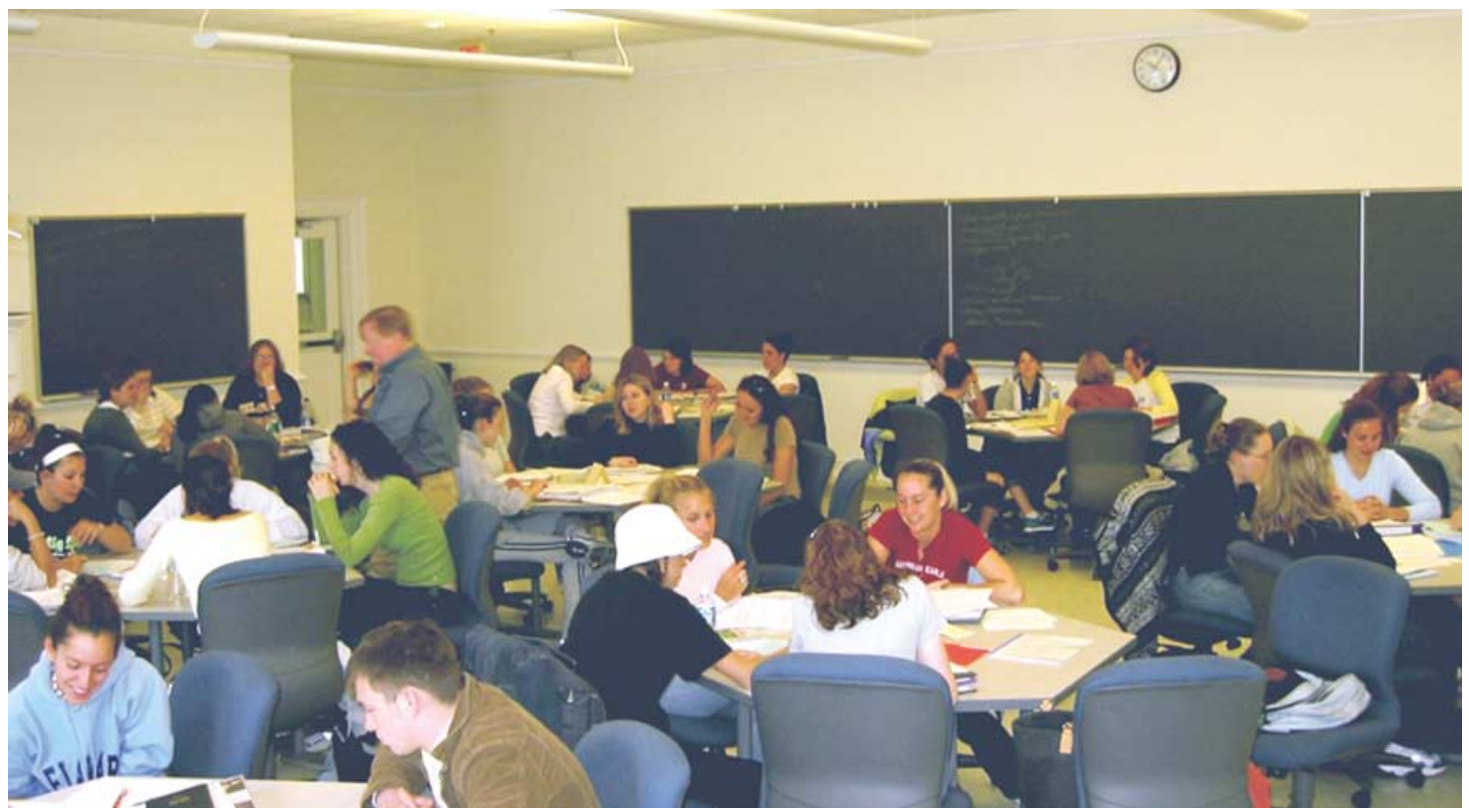

Figure 1. An interdisciplinary science course for elementary teacher education majors.

preparation or formal study-in contrast to the more common use of classroom problems to hone or assess a learner's ability to apply previously learned content and procedural skills. Finally, PBL incorporates a formal learning cycle of activities (as described below) that may take as much as several weeks to complete, depending on the nature of the problem.

\section{THE PBL CYCLE}

As originally formulated in a professional school setting over 40 years ago, the idealized learning cycle used in PBL takes place using the following steps. When first presented with the problem, students begin by organizing their ideas and related previous knowledge and by attempting to define the problem's broad nature. They then pose questions on aspects of the problem that they do not understand and decide which questions should be followed up by the whole group and which can be assigned to individual students to research independently. When the students reconvene, they present to one another the findings from their research on the questions posed in the previous session, integrating their new knowledge and skills into the context of the problem. The students continue to define new areas of needed learning (digging progressively deeper into the underlying content and assumptions) as they work through the problem, which typically enfolds in several stages (Barrows and Tamblyn; 1980; Engle, 1998).

Students engaged in PBL continually and explicitly expand (redefine for themselves) the boundaries between their prior knowledge and the knowledge they now need. By requiring students to assess their own knowledge, to recognize deficiencies, and to obtain the desired information through their own investigations, PBL models an authentic process of learning that can be used beyond the college experience (Engle, 1998).

\section{PBL PROBLEMS}

A major roadblock when PBL was first implemented in undergraduate courses, particularly in the introductory basic sciences, was the absence of suitable problems, an important concern because of the central role that problems play in initiating and organizing the learning. To meet the goals of PBL instruction, these problems must be able to stimulate active, cooperative learning activities within student groups for up to a week or more. End-of-chapter textbook problems in general do not require the analytical, synthetic, and evaluative thinking needed for PBL, nor do they provide the contextual richness (Duch, 1996; White, 1996). Consequently, a major "problem" for adapting PBL was the necessity to write problems appropriate to the instructional goals. Fortunately, this barrier is being lowered as more and more faculty drawn to PBL are willing to turn their creative energies toward writing and disseminating course materials for use at the college level.

Faculty who write problems turn to a variety of sources for inspiration-landmark experiments (e.g., Dating Eve [White, 1995]); popular press articles about recent discoveries, inventions, or ethical dilemmas (e.g., Who Owns the Geritol Solution? [Allen, 2002] and Should Dinosaurs Be Cloned from Ancient DNA? [Soja and Huerta, 2000]); or even "factual fiction" accounts of ways in which central concepts of a particular discipline might impact the average person's life (e.g., When Twins Marry Twins [Allen, 1998], Snake Bite! [Bassham and Santos, 2002], What's Wrong with Amadi? [Russin, 2002], Mad Cows and Englishmen [Schmieg, 2002], and What Did You Say Doc [Tallitsch, 2002]). Synopses of these problems, and additional life science examples, are included in Table 1. A book chapter by Donham et al. (2001) provides a typical sequence of problems that could be used in an introductory biology course for undergraduates, with their topical objectives. 
Table 1. Sample problems and problem topics for undergraduate life sciences education

\begin{tabular}{|c|c|c|}
\hline Problem title (and author) & Synopsis & Topics uncovered in PBL cycle ${ }^{a}$ \\
\hline $\begin{array}{l}\text { A Case of Mass Fainting } \\
\text { (P. Ommundsen) }\end{array}$ & $\begin{array}{l}\text { What caused } 400 \text { people attending } \\
\text { a rock concert to become faint or } \\
\text { collapse? }\end{array}$ & $\begin{array}{l}\text { Metabolic effects of fasting; } \\
\text { sequelae of hyperventilation- } \\
\text { induced cerebral } \\
\text { vasoconstriction, Valsalva } \\
\text { pressure }\end{array}$ \\
\hline Dating Eve (H. White) & $\begin{array}{l}\text { Analysis of key experimental } \\
\text { evidence for the "Eve } \\
\text { hypothesis" and controversies } \\
\text { over identification of human's } \\
\text { most recent common ancestor. }\end{array}$ & $\begin{array}{l}\text { Construction of phylogenetic trees } \\
\text { from sequence data; the } \\
\text { molecular clock hypothesis and } \\
\text { its assumptions and calibration } \\
\text { for mitochondrial DNA; } \\
\text { comparison of evidence from } \\
\text { the fossil record versus that from } \\
\text { molecular biology }\end{array}$ \\
\hline
\end{tabular}

\section{Fecal Coliforms in Antarctica (S.C. Nold)}

Kryptonite in His
Pocket? (R. Donham)

\author{
Mad Cows and \\ Englishmen \\ (F. Schmieg)
}

Out of Control (L. Dion)
Students design experiments to assess the impact of disposal of untreated sewage from an Antarctic research station into the ocean, and decide what actions, if any, should be taken.

Greg LeMond dominated the sport of cycling in the mid- to late 1980s; his performance abruptly plummeted and he announced his retirement in the early 1990s. Was he "over the hill" or was an earlier hunting injury finally catching up with him?

A college student serves on a panel charged with writing a travel advisory for students planning to attend Winter Session in England. Given the potential problems with Mad Cow Disease in England, what should the panel advise?

The population of lesser snow geese is growing exponentially in the U.S. and Canada. What factors are contributing to this population explosion, and what impact is it having on U.S. and Canadian ecosystems?

Michael Crichton's Jurassic Park reawakened the public's fascination with dinosaurs. What if we could actually bring them back to life? How close are we to creating Jurassic Park?

Water, Water, Everywhere (D. Allen)
Shipwrecked boaters run out of drinking water and

Source $^{b}$

In PBL in Biology. Available at http://www.saltspring.com/ capewest/pbl.htm

1995. In: University of Delaware. Problem-Based Learning. Available at http://www.udel. edu/pbl/curric/chem647prob. $\mathrm{html}$

How scientists organize experiments, including appropriate use of controls; data collection and analysis; how scientific data inform policy makers; fecal coliform detection methods

Cellular energy conversions; organelles of energy conversion; the role of mitochondrial DNA and how it is inherited

The role of protein folding and structure in the control of protein function; how abnormal proteins can lead to disease

Population dynamics-growth curve of an exponentially growing population; effect of carrying capacity; survivorship curves; examples of interspecific relationships in communities; differences in ecosystems (tundra versus cultivated grasslands in U.S.)

Dinosaurs, their diversity, distribution, physiology, behavior, environmental requirements, and extinction; techniques used to discover and retrieve ancient DNA and to produce a clone from a living adult animal

Operation of homeostatic control systems, particularly roles of
2002. In: National Center for Case Study Teaching in Science. Case Collection. Available at http:// ublib.buffalo.edu/libraries/ projects/cases/case.html

1998. In: D.E. Allen and B.J. Duch (eds.), Thinking Towards Solutions: Problem-Based Learning Activities for General Biology. Philadelphia, PA: Saunders College

2002. In: PBL Clearinghouse. Available at https://www.mis4. udel.edu/Pbl/index.jsp

2001. In: PBL Clearinghouse. Available at https://www.mis4. udel.edu/Pbl/index.jsp

2002. National Center for Case Study Teaching in Science. Case Collection. Available at http:// ublib.buffalo.edu/libraries / projects/cases/case.html

1998. In: D.E. Allen and B.J. Duch (eds.), Thinking Towards 
Table 1. Continued

Problem title (and author) Synopsis $\quad$ Topics uncovered in PBL cycle Source $^{a}$

wonder if seawater is potable. One boater has a far more serious level of dehydrationWhat is his problem?

What Did You Say Doc (R. Tallitsch)

\begin{abstract}
What's Wrong with
Amadi (J. Russin)
\end{abstract}

When Twins Marry Twins (D. Allen)

\author{
A 41-year-old machinist, \\ complains of difficulty with \\ hearing in the right ear and \\ has an unsteady gait and \\ occasional missteps with his \\ right leg. What is wrong? Where \\ in the nervous system does the \\ injury originate? \\ Amadi, a Nigerian exchange \\ student, doubles over in pain \\ while playing soccer, and later \\ develops big sores on his leg. \\ What's wrong with Amadi?
Each member of a set of identical twins marries a twin from another set. One expectant twin wonders if her child will be identical to his "double cousin," whose appearance is rather unfortunate.

hormonal systems in body fluid and electrolyte balance; kidney concentrating mechanisms; input-output relationships and the body's fluid compartment composition.

Three-dimensional understanding of the functional anatomy of the brain stem and cranial nerves.
Solutions: Problem-Based Learning Activities for General Biology. Philadelphia, PA: Saunders College.

2002. In: PBL Clearinghouse. Available at https://www.mis4. udel.edu/Pbl/index.jsp
Levels of protein structure; structure and function of hemoglobin in health and disease; molecular basis of pathological changes in hemoglobin.

Cell division; early embryogenesis; mechanisms of genetic inheritance; role of genotype versus environment in determining phenotype.
2002. In: Southeast Missouri State University and BioQUEST Curriculum Consortium, Life Lines Online.

1998. In: D.E. Allen and B.J. Duch (eds.), Thinking Towards Solutions: Problem-Based Learning Activities for General Biology. Philadelphia, PA: Saunders College.

${ }^{a}$ Topics that would allow students to pinpoint problem solutions are not included in this list, except in cases in which these are already available on the Internet.

${ }^{b}$ Full citations are included in the References, listed by author.

Two faculty at the University of Delaware use problems that provide students with an explicit model for scientific research. Harold White (1996) uses a carefully selected series of primary research articles around the theme of hemoglobin to generate PBL problems in an introductory biochemistry course. David Sheppard has constructed a series of problems around important areas of recent discovery in the field of genetics in a course required for all biology majors. The problems allow students to develop their ability to access research-quality (nucleic acid and protein) databases, analyze and make sense of their findings, and apply these findings to resolution of the problems.

One of the problems mentioned above (Who Owns the Geritol Solution? [Allen, 2002]) can be used to illustrate one of the many ways in which problems are constructed. Student interest is engaged by introducing them to a long-standing "mystery" in the field of marine biology: Why are vast areas of the open ocean so unproductive, biologically speaking, yet seemingly so nutrient-rich? The problem text goes on to recount, in intentionally sketchy fashion, studies by John Martin and colleagues that suggested that the missing ingredient in these ocean areas is iron. In the public and formal arena of a scien- tific meeting, Martin went on to propose that by dosing these waters with an iron tonic, we could harness the latent primary productivity of marine phytoplankton to lessen the impact of excess carbon dioxide emissions on global warming. Or, as he so provocatively said, "Give me a tanker full of iron, and I'll give you an ice age." In the context of this "Geritol solution," students encounter and are asked to make connections between major concepts related to global biogeochemical cycles, cellular energy transformations, marine ecosystems, and global climate changes. Study of the cellular events is more intriguing to students because the problem places these in a larger scale, more tangible context.

As summarized in Table 2 (which also summarizes the student and instructor roles and responsibilities), the stages of the problem are as follows. In the first stage, students are asked to integrate processes at many levels of biological organization to figure out how the Geritol solution might work, to estimate how much iron would be needed to ameliorate our annual excess carbon dioxide emissions, to brainstorm about the essential design features of an experiment to test the iron seeding hypothesis in the open ocean, and, finally, to decide whether they would approve funding of such an 
experiment with "taxpayers' dollars." After investigating the concepts underlying how the Geritol solution might work to gain deeper understandings, then analyzing the results of actual attempts to test the iron hypothesis, students move on to the second and final stage of the problem. In this stage they are asked to engage in additional environmental decision making concerning the patenting and commercial use of the Geritol solution for fish farming and carbon sequestration by an environmental engineering firm.

\section{USING PBL IN UNDERGRADUATE COURSES}

Use of PBL in the undergraduate setting entails a judicious and individualized response to the issues its implementation raises, including the following: (1) How and when do I introduce the idea to my students? (2) How do I time and schedule PBL within the context of my course and my department's curriculum? (3) How will my course content objectives be met? (4) Will I have support for the risks inherent in revamping my course to a more student-centered format? (5) How will students' individual success at learning be identified and evaluated? (6) Does my institution have a classroom configured to facilitate group learning? and (7) How will I organize and monitor the PBL groups? In the short space of this column, we can highlight typical answers to only a few of these implementation issues but hope that this will spur the reader to consult the many additional resources cited in the References at the end of the column.

As is the case for other forms of active or inquiry-based learning, PBL empowers students to take a responsible role in their learning - and as a result, faculty must be ready to yield some of their authority in the classroom to their students. The PBL instructor serves as a cognitive coach-guiding, probing, and supporting students' initiatives (Mayo et al., 1995), rather than lecturing, directing, or providing ready answers. In the earliest models of PBL, the PBL group facilitator (or "tutor") worked with a single group (Engle, 1998) of up to 14 students, a faculty-to-student ratio that was hard to reproduce when PBL began to be implemented in the undergraduate setting. The difficulties inherent in scaffolding students' knowledge construction in larger enrollment classes (too large for a single PBL group) were among the challenges faced by faculty attempting to adapt PBL to the typical undergraduate setting

Table 2. Use of PBL to frame student learning in a sample problem, "Who Owns the Geritol Solution?"

Class session ${ }^{b}$

problem stage
Driving question(s)
Content themes
Student activities \& responsibilities
Instructor roles \& responsibilities
Session 1/Stage $1 \quad$ Stage $1:^{c}$ (1) How does the Geritol solution work? (2) How does one design mesoscale-sized experiments in a natural environment?
Stage 1: Greenhouse gases and evidence for global warming; $\mathrm{CO}_{2}$ and photosynthesis; photosynthetic pigments; marine food webs; global carbon cycle, including role of marine producers, consumers, and decomposers; assumptions of scale on experimental design
- Read, discuss problem in group

- List/discuss prior knowledge that relates to problem

- Develop, prioritize questions that lead to new information

- Prioritize, assign responsibilities for outof-class research; discuss potential sources

- Introductory remarks: situate problem within the context of the course distribute Part 1

- Observe group discussions

- Facilitate (if necessary) development \& prioritization of learning issues

- Monitor group functioning-sharing of responsibilities and tasks; participation in discussions

Students' out-of-class individual research on question-driven topics

Session $2 \&$
beginning of
3/Part 1
continued

Stage 1: (1) Would you fund an open ocean test of the Geritol solution?

$\begin{array}{cc}\text { Session 3/Stage } 2 \quad & \text { Stage } 2:^{d}(1) \text { Is the Geritol } \\ & \text { solution a desirable } \\ & \text { solution for } \\ & \text { environmental } \\ \text { problems? }\end{array}$

\section{Stage 1: Refinement and enrichment of student understanding of content issues \\ Analysis of actual tests of Geritol solution (Iron Ex and SOIREE experiments)}

Stage 2: Commercial use of the Geritol solution for carbon sequestration and fish farming; potential environmental impact; Kyoto protocol; cost benefit analysis of ocean iron fertilization
- Reporting on out-of-class research at beginning of 2nd session

- Apply \& discuss new understanding to problem; refine learning issues for further out-ofclass research

- Application of prior knowledge to new information about commercial use, develop new learning issues for out-of-class research
- Observe group discussions, whole-class discussions, and minilectures as necessary to facilitate, focus student inquiry

- Distribute Part 2 in final 20-25 min of class

- Facilitate new learning issue development (if necessary) 
Table 2. Continued

Class session ${ }^{b}$ / problem stage
Driving question(s)
Content themes
Student activities \& responsibilities
Instructor roles \& responsibilities
Students' out-of-class individual research on question-driven topics

\begin{tabular}{|c|c|}
\hline $\begin{array}{r}\text { Optional Session } \\
4 / \text { Stages } 1 \& 2\end{array}$ & $\begin{array}{l}\text { Concept map: (1) What } \\
\text { the big ideas? (2) How } \\
\text { all of these pieces of } \\
\text { formation interconnec }\end{array}$ \\
\hline $\begin{array}{l}\text { Session } 4 \text { or } \\
\text { 5: Problem } \\
\text { resolution }\end{array}$ & $\begin{array}{l}\text { Problem resolution: (1) } \\
\text { What do we still not } \\
\text { understand? (2) How } \\
\text { can we do better next } \\
\text { time? }\end{array}$ \\
\hline
\end{tabular}
See above for Stages 1
and 2

Refinement and strengthening of content understanding of Parts 1 and 2

Assessment of group and individual achievement

\author{
Construct maps based on \\ group's current \\ understanding of \\ complex topics
}

- Final reporting on out-ofclass individual research, discussion of the content environmental issues

- Organize work on group assignment or product: position paper and debate, letter to editor of newspaper or journal, or dialogue

- Reflection on the problem-resolving process
Formative assessment possibility: concept map (if necessary, introduce students to methodology)

- Observe group function

- Distribution of instructor-identified learning objectives

- Minilectures if needed to clarify concepts students identify as still poorly understood

- Lead whole-class discussions to facilitate connections with previous problems

Future individual assessment: Exam questions

${ }^{a}$ In PBL Clearinghouse. Available at https://www.mis4.udel.edu/Pbl/index.jsp.

${ }^{b}$ Class sessions of 75-min duration.

${ }^{c}$ In Stage 1 of this problem, students are introduced to a long-standing "mystery" in the field of marine biology: why vast areas of the open ocean are so unproductive, yet seemingly so nutrient-rich. Stage 1 briefly summarizes studies by John Martin and colleagues that suggested that the missing ingredient in these waters is iron. It ends with Martin's provocative proposal at a public scientific meeting that by dosing these waters with an iron tonic, we could harness the latent primary productivity of marine phytoplankton to lessen the impact of excess carbon dioxide emissions on global warming. In the context of an intentionally sketchy description of this "mystery" and Martin's so-called "Geritol solution," students are asked to figure out how the Geritol solution might work, to estimate how much iron would be needed to ameliorate our annual excess carbon dioxide emissions, to brainstorm about the essential design features of an experiment to test the iron seeding hypothesis in the open ocean, and to decide whether they would approve federal funding of such an experiment. In doing so they make essential connections among major concepts related to global biogeochemical cycles, cellular energy transformations, marine ecosystems, and global climate changes. ${ }^{d}$ In Stage 2, students are asked to engage in additional environmental decision making concerning the patenting and commercial use of the Geritol solution for fish farming and carbon sequestration by an environmental engineering firm. Stage 2 briefly describes one of these firms and ends with a provocative quote by its owner that discounts any potential for serious environment impact of large-scale use of the Geritol solution. In working through this stage, students research and analyze past "tests" of the Geritol solution's effectiveness and consider broad issues in environmental science, including ownership of the "commons."

(Allen et al., 1996). How, then, might PBL instructors facilitate many classroom groups simultaneously?

One strategy for monitoring multiple groups has features that work for collaborative learning settings in general. The instructor walks around the classroom, looking and listening for signs that the groups are engaged and on track and that all members are participants in the group discussion. The "roving" instructor may also enter into discussions, pose questions, look for overt signs of behaviors that undermine group function, or otherwise focus on a particular group for a short period of time.

This roving facilitator strategy is particularly effective if the PBL problems are constructed so that instructor-led, wholeclass discussions can be inserted at key intervals in the problem-resolving process. Groups can then compare notes on each other's progress and the instructor can simultaneously give all groups essential feedback or guidance. This can include tips on finding important resources, helping students beyond conceptual impasses, and encouraging students to dig more deeply into topics whose understanding will enrich their passage through the problem. In essence, faculty using this model are striving to supply to the whole class in a structured way the guidance supplied by the classic PBL facilitator more informally and extemporaneously. The roles and responsibilities of the PBL instructor, in addition to the roles and responsibilities of the students, are summarized in the context of a sample problem in Table 2.

Another model is to enlist the help of other undergraduates to serve as peer or near-peer facilitators (Allen and White, 1999). That is, students, who have completed a course and done well return to work in the PBL classroom as group facilitators. They can serve as a "dedicated" facilitator for a single classroom group or as a "roving" facilitator along with the faculty instructor.

In these models for implementation of PBL in undergraduate courses, instructors typically set up structures for group 
operation that are similar to those used in cooperative learning classrooms (Tanner et al., 2003). Group composition is selected by the instructor (rather than allowing students to self-select their group members), and group size is typically kept at four students (with a slightly larger size possible when peer facilitators are present). Additional procedures that help to maintain group process include drafting group guidelines or ground rules, assigning rotating roles of responsibility for group members, and requiring periodic oral and written feedback (through peer assessment) on individual contributions to the PBL effort. Student groups draft their own ground rules at the start of the semester and refer to them as needed. Typical ground rules drafted by students incorporate policies on attendance and preparedness, plus an escalating sequence of penalties for each failure to adhere to the guidelines. Roles of responsibility, which rotate among group members on a regular time schedule or with each new problem, typically include a discussion leader, a reporter (for group products and class discussions), a recorder, and an accuracy coach (the "skeptic").

\section{ADDITIONAL STRATEGIES FOR USING PBL IN LARGE ENROLLMENT COURSES}

Instructors can implement PBL in a setting in which enrollment is greater than 60 students using many of the previously mentioned strategies. They enlist the help of undergraduate and graduate TAs to have more individuals to monitor groups. They use carefully staged problems that allow the instructor to intervene at roughly 15- to 20-min intervals to help guide students' progress through the problem. The instructors typically choose to provide more input into group monitoring strategies such as rotating roles and ground rules. Group evaluations are often based on students' comments and ratings of each other's contributions to assignments and products or are based on highly streamlined versions of the written and verbal feedback strategies used in smaller-class PBL (Barrows and Tamblyn, 1980).

PBL instructors of these larger enrollment classes also intersperse other classroom activities between and within the course of PBL problems. In these hybrid models, a PBL problem often serves as the central focus of a unit of instruction, but lectures, discussions, and short active learning activities associated with the problem help students to build conceptual frameworks. Instructors teaching large classes have found that use of either one longer problem in which a clearly delineated final product is embedded (for example, a position paper that serves as a prelude to a whole-class debate, mock trial, town meeting, or congressional hearing) or four to six short problems, one for each major content unit (Donham et al., 2001), is a manageable strategy. Others conduct the PBL elements of the course in laboratory, discussion, or recitation sections in which the class meets in smaller subunits. However, if these sections are taught by teaching assistants who are not familiar with PBL and its underlying goals and assumptions, this becomes a less than optimal strategy (Shipman and Duch, 2001).

\section{ASSESSMENT OF PBL OUTCOMES}

Faculty using PBL instruction in an undergraduate setting typically have ambitious goals for student learning in addi- tion to understanding of the content material of the course. These can include students' development of the ability (1) to communicate results of an investigation or research project orally, graphically, and in writing; (2) to pose questions that guide self-directed learning and the learning of others; (3) to identify, find, and analyze information that is needed for a particular task; (4) to collaborate productively in teams; (5) to reason critically and creatively; and (6) to make reasoned decisions in unfamiliar situations. Attainment of the first four of these goals within a given PBL course can be documented by comparison of student performance on exams, lab reports, formal oral presentations, peer group evaluations, classroom observations, and/or written assignments at the start and the end of the semester. Documentation of student achievement of the fifth and sixth goals is hampered by lack of instruments that have the sensitivity needed to detect changes in critical thinking (as defined by particular instructors or within particular disciplines) over the course of a semester.

Although PBL is not a method designed for the explicit purpose of enhancing content understanding, faculty using PBL are often asked whether learning of essential course content suffers because of time spent on these ambitious process objectives. Studies summarizing 20 years of experience from the medical school setting (as reviewed by Albanese and Mitchell, 1993) as well as specific experiences with a PBL curriculum (Kaufmann et al., 1989) have led to the general conclusion that content mastery in a problem-based curriculum is as good as in a traditional one, but retention of knowledge and satisfaction with the school experience are greater with PBL.

In the undergraduate setting, the existence of standardized tests with national databases in some disciplines in the basic sciences has also allowed for content learning comparisons between PBL and more traditional courses. For example, in a PBL course in introductory physics, Williams (2001) reports gains in the force-concepts inventory consistent with averages in other courses that use interactive-engagement methods and nearly twice that of the average in courses using traditional methods with little interactive engagement (Hake, 1998). Even when conducted using this type of instrument, however, comparison of student outcomes in PBL courses with those of courses using other strategies can present difficulties. Comparison of students' scores on content-based multiple choice pre- and posttests, for example, captures only one of the goals (understanding of course content) of the PBL experience and neglects the others. Conversely, it would be inappropriate to evaluate students in lecture-based courses with instruments that assess PBL's additional goals (for example, ability to communicate, to identify, find, analyze, and apply information needed for a particular task, or to work productively in a team) if the students had had little opportunity to practice these skills during the conduct of the courses.

\section{RESOURCES FOR PBL IMPLEMENTATION}

\section{Sources of Problems}

For instructors who would like to use PBL, several collections of problems are available online. Online sources include (1) Life Lines On-Line, a collection of introductory life sciences problems produced through a collaboration between Southeast Missouri University and the BioQUEST Curriculum Consortium; (2) the National Center for Case 
Study Teaching in Science's (State University of New York at Buffalo) case collection, which includes some case studies that can be used for PBL instruction (National Center for Case Study Teaching in Science); (3) a set of pharmacology problems written by P.K. Rangachari at McMaster University; (4) a collection of 20 biology cases (PBL in Biology) written by P. Ommundsen; (5) the PBL Clearinghouse (University of Delaware), which contains problems and teaching notes for the sciences and disciplines outside the sciences; and (6) other sources (see Table 1 for examples of case titles and content areas). Links to these Web sites are included in the list of references at the end of this column.

Books containing PBL problems are less common, but several exist (Allen and Duch, 1998; Newton, 2001; Rosen and Geha, 2001). Instructors will typically want to revise the problems or cases in these books (as well as the ones accessed on the Internet). To be used in PBL, case study examples might need to be restructured into a staged format or so as to provide less information in order to motivate students' independent research. Michael and Rovick's (1999) Problem Solving in Physiology contains staged problems that focus on answering challenging questions linked to key areas of physiology content. The book provides an Answers section, however, that might preclude its use in a PBL context unless students' access could be restricted until after they had reached their own resolutions.

\section{Workshops on PBL}

Giving up the safety and authority of the front of the classroom can be unsettling for faculty accustomed only to a traditional teacher-centered lecture format (Uno, 1997). Fortunately, a number of institutes and institutions (Southeast Missouri State University and BioQUEST, Southern Illinois University, University of California, Irvine, and University of Delaware, to name a few; see links to the associated Web sites in the References) offer 1-day to 1-week-long "handson" workshops that are often facilitated by faculty who have transformed their own teaching of undergraduate courses to use PBL. These workshop experiences provide the support, resources, and training needed to encourage participants to in turn transform their courses to incorporate PBL and related active learning strategies.

\section{FINAL NOTE}

Problem-based learning is alive and flourishing in the medical and professional school setting that gave rise to the method (Samford University, PBL Initiative) and has numerous proponents and practitioners in the $\mathrm{K}-12$ education community (Torp and Sage, 1998). With apologies to the many dedicated PBL instructors in these settings (and to the many practitioners worldwide), the focus of this column has been on PBL implementation in the undergraduate setting in the United States-simply because this is the context with which the corresponding author is most familiar. We hope that the references and resources provided can further inform the reader about these other important settings.

\section{ACCESS TO MATERIALS}

The PBL Clearinghouse is on a secure server, and potential users must register to have access to the materials therein.
(This process was designed to prevent students from having access to later stages of problems before resolving earlier ones, and to teaching notes and resolution scenarios.) Once user application is successful, the materials can be downloaded and used without charge or obligation.

\section{REFERENCES}

Albanese, M.A., and Mitchell, S. (1993). Problem-based learning: A review of literature on its outcomes and implementation issues. Acad. Med. 68, 52-81.

Allen, D.E. (1998). When twins marry twins; Water, water, everywhere. In: Thinking Towards Solutions: Problem-Based Learning Activities for General Biology, ed. D.E. Allen and B.J. Duch. Philadelphia, PA: Saunders College.

Allen, D.E. (2002). Who owns the Geritol solution? In: University of Delaware PBL Clearinghouse. Available at https://www. mis4.udel.edu/Pbl/index.jsp.

Allen, D.E., and Duch, B.J. eds. (1998). Thinking Towards Solutions: Problem-Based Learning Activities for General Biology. Philadelphia, PA: Saunders College.

Allen, D.E., and White, H.B., III (1999). A few steps ahead on the same path: Using peer tutors in the cooperative learning classroom-A multilayered approach to teaching. J. College Sci. Teach. 28, 299-302.

American Association for the Advancement of Science. (1990). The liberal art of science: Agenda for action. In Report of the Project on Liberal Education and the Sciences. Washington, DC: AAAS.

Barrows, H.S., and Tamblyn, R.N. (1980). Problem-Based Learning: An Approach to Medical Education. New York: Springer.

Boud, D., and Feletti, G. (1998). Changing problem-based learning: Introduction to the second edition. In: The Challenge of ProblemBased Learning, ed. D. Boud and G. Feletti. London: Kogan Page.

Boyer Commission on Educating Undergraduates in the Research University for the Carnegie Foundation for the Advancement of Teaching. (1998). Reinventing Undergraduate Education: A Blueprint for America's Research Universities. Available at http:/ / naples.cc.sunysb.edu/Pres/boyer.nsf.

Dion, L. (2001). Out of control. In: Problem-Based Learning Clearinghouse. Available at https://www.mis4.udel.edu/Pbl/index.jsp.

Donham, R. (1998). Kryptonite in his pocket? In: Thinking Towards Solutions: Problem-Based Learning Activities for General Biology, ed. D.E. Allen and B.J. Duch. Philadelphia, PA: Saunders College.

Donham, R.S., Schmieg, F.I., and Allen, D.E. (2001). The large and the small of it: A case study of introductory biology courses. In: The Power of Problem-Based Learning: A Practical 'How To' for Teaching Courses in Any Discipline, ed. B.J. Duch, S.E. Groh, and D.E. Allen. Sterling, VA: Stylus.

Duch, B.J. (1996). Problems: A key factor in PBL. About Teach. 50(Spring), 7-8.

Engle, C.E. (1998). Not just a method but a way of learning. In: The Challenge of Problem-Based Learning, ed. D. Boud and G. Feletti. London: Kogan Page.

Festinger, L. (1962). Cognitive dissonance. Sci. Am. 210, 93-102.

Hake, R.R. (1998). Interactive-engagement versus traditional methods: A six-thousand student survey of mechanics test data for introductory physics course. Am. J. Phys. 66, 64-74.

Kaufman, A., Mennin, S., Waterman, R., Duban, S., Hansbarger, C., Silverblatt, H., Obenshain, S.S., Kantrowitz, M. Becker, T., Samet, J., and Wiese, W. (1989). The New Mexico experiment: Educational innovation and institutional change. Acad. Med. 64, 285-294. 
Mayo, W.P., Donnelly, M.B., and Schwartz, R.W. (1995). Characteristics of the ideal problem-based learning tutor in clinical medicine. Eval. Health Prof. 18, 124-136.

Michael, J.A., and Rovick, R.A. (1999). Problem Solving in Physiology. Upper Saddle River, NJ: Prentice Hall.

National Center for Case Study Teaching in Science (C.F. Herreid and N. Schiller, Directors, State University of New York at Buffalo). Case Collection. Available at http://ublib.buffalo.edu/libraries/ projects/cases/case.html.

National Science Foundation (1997). Curricular Developments in the Analytical Sciences. Arlington, VA: NSF.

Newton, L.H. (2001). Watersheds 3: Ten Cases in Environmental Ethics. Belmont, CA: Wadsworth

Nold, S.C. (2002). Fecal coliforms in Antarctica. In: National Center for Case Study Teaching in Science. Case Collection. Available at http://ublib.buffalo.edu/libraries/projects/cases/case. html.

Ommundsen, P. A case of mass fainting. In: PBL in Biology. Available at http:/ / www.saltspring.com/capewest/pbl.htm.

Qin, Z., Johnson, D.W., and Johnson, R.T. (1995). Cooperative versus competitive efforts and problem-solving. Rev. Educa. Res. 65, 129143.

Rangachari, P.K. Department of Pharmacology, McMaster University. Problem writing: A Personal Casebook. Available at http://www.fhs.mcmaster.ca/pbls/writing/contents.htm.

Rosen, F.S., and Geha, R.S. (2001). Case Studies in Immunology: A Clinical Companion. New York: Garland.

Russin, J. (2002). What's wrong with Amadi? In: Southeast Missouri State University and BioQUEST Curriculum Consortium, Life Lines Online. Available at http:/ / bioquest.org/lifelines/.

Samford University. Who is doing problem-based learning? (searchable database). In: Samford PBL Initiative. Available at http://www.samford.edu/pbl/who.html.

Schmieg, F. (2002). Mad cows and Englishmen. In: ProblemBased Learning Clearinghouse. Available at https://www.mis4. udel.edu/Pbl/index.jsp.

Shipman, H.L., and Duch, B.J. (2001). Problem-based learning in large and very large classes. In: The Power of Problem-Based Learning: A Practical 'How To' for Teaching Courses in Any Discipline, ed. B.J. Duch, S.E. Groh, and D.E. Allen. Sterling, VA: Stylus.
Soja, C.M., and Huerta, D. (2002). Should dinosaurs be cloned from ancient DNA? In: National Center for Case Study Teaching in Science Case Collection. Available at http://ublib.buffalo.edu/ libraries/projects/cases/case.html.

Southeast Missouri State University amp BioQUEST Curriculum Consortium. Life Lines Online. Available at http://bioquest.org/ lifelines/.

Tallitsch, R. What did you say Doc. In: Problem-Based Learning Clearinghouse. Available at https://www.mis4.udel.edu/Pbl/index.jsp.

Tanner, K., Chatman, L. S., and Allen, D. (2003). Cooperative learning in the science classroom-Beyond students working in groups. Cell Biol. Educ. 2, 1-5.

Torp, L., and Sage, S. (1998). Problems as Possibilities-ProblemBased Learning for K-12 Education. Alexandria, VA: Association for Supervision and Curriculum Development.

University of California, Irvine. Problem-Based Learning Faculty Institute. Available at http://www.pbl.uci.edu/.

University of Delaware. Calendar of activities. Institute for Transforming Undergraduate Education. Available at http://www.udel. edu/inst/calendar.html

University of Delaware. Problem-Based Learning Clearinghouse. Available at https://www.mis4.udel.edu/Pbl/index.jsp.

University of Southern Illinois School of Medicine. Problem-Based Learning Initiative. Available at http://www.pbli.org/workshops/ index.htm.

Uno, G.E. (1997). Learning about learning through teaching about inquiry. In: Student-Active Science: Models of Innovation in College Science Teaching, ed. C.D'Avanzo and A.P. McNeal. Philadelphia, PA: Saunders College.

White, H.B., III. (1996). Addressing content in problem-based courses: The learning issue matrix. Biochem. Educ. 24, 41-45.

White, H.B., III (1995). Dating Eve. In: University of Delaware Problem-Based Learning. Available at http://www.udel.edu/pbl/ curric/chem647prob.html

Williams, B.A. (2001). Introductory physics: A problem-based model. In: The Power of Problem-Based Learning: A Practical 'How To' for Teaching Courses in Any Discipline, ed. B.J. Duch, S.E. Groh, and D.E. Allen. Sterling, VA: Stylus.

Woods, D. (1985). Problem-based learning and problem-solving. In Problem-Based Learning for the Professions, ed. D. Boud. Sydney: HERDSA. 